\title{
Effects of cardiac rehabilitation treatment modalities in Sub-Saharan Africa: A systematic review
}

\author{
Alice Namanja ${ }^{1}$, Anas Usman ${ }^{2}$, Toyin Odunuga ${ }^{3}$ \\ 1. Department of Physiotherapy, Kamuzu University of Health Sciences, Malawi \\ 2. Department of Physiotherapy, Apollo Hospital, India \\ 3. Cardiac Rehabilitation Unit, Royal Stoke Hospital, United Kingdom
}

*Corresponding Author: Alice Namanja; anamanja@medcol.mw

\begin{abstract}
Purpose
Although Cardiac Rehabilitation (CR) implementation models recommend delivery of any CR treatment component, Sub-Saharan Africa (SSA) constitutes only $17 \%$ of globally available CR programs. The aims of this review were to assess the benefits of employing any CR treatment modality in SSA, and evaluate if this approach should be encouraged in this resource-constrained region.

Methodology

Records were identified electronically via CINAHL, MEDLINE, Cochrane library, African journal online, PubMed, Web of science and google scholar, and grey literature was hand-searched. Articles reporting effectiveness of any CR treatment modality were included if participants had any cardiovascular disease and if the study was conducted in SSA. Quality assessment for each enrolled study was done using Downs and Black (1998) checklist and data was extracted using a modified standard tool.

Results

Searches identified 1666 records, 24 full text articles were examined and 10 were included for the review; 60\%, 30\% and 10\% of the enrolled studies were done in South Africa, Nigeria and Benin respectively. The studies implemented exercise, psychosocial and education treatment modalities of CR, and the approach of delivery was either comprehensive or modified. Comprehensive CR and delivery of combined aerobic and resistance exercises improved physical $(13 \%, \mathrm{p}=0.001)$, social $(40 \%, \mathrm{p}=0.001)$ and mental aspects of quality of life and reduced anxiety $(-12 \%, \mathrm{p}<0.05)$ and depression $(-6 \%, \mathrm{p}<0.001)$ respectively. Comprehensive CR and aerobic training both reduced systolic blood pressure (range of mean reduction [RMR] - 6 to $-14 \mathrm{mmHg}$ ), diastolic blood pressure (RMR -4 to $-6 \mathrm{mmHg}$ ) and resting heart rate (RMR -7 to $-17 \mathrm{bpm})$. Overall, all types of exercises showed a $1-5 \mathrm{ml} . \mathrm{kg}-1 . \mathrm{min}-1$ increase in peak oxygen consumption.

Conclusion

The findings support delivery of exercise treatment modality and comprehensive delivery of CR in SSA. However, efficacy of independent implementation of education and psychosocial therapeutic components of CR remains unclear; hence the need for further investigations.
\end{abstract}

Abstract

Key words: Cardiac Rehabilitation, Treatment Components, Models, Sub-Saharan Africa

\section{Introduction}

Cardiovascular disease (CVD) is a term used to describe the diseased state of heart and blood vessels ${ }^{1}$ induced by alterable and non-alterable influencing factors ${ }^{2}$. While aging, sex, race and genetic make-up constitute the non-modifiable CVD predisposing factors, smoking, unhealthy eating and sedentary lifestyles are considered the main correctable causes ${ }^{3,4}$. Childhood malnutrition and exposure to fumes from cooking fuels also attribute to development of CVD among people from the Sub-Saharan Africa (SSA) ${ }^{5,6}$. This entails complexity in the causation and presentation of the CVD, which may also be fueled by the existence of other co-morbidities ${ }^{7}$. Patients with Coronary Heart Disease (CHD) and Heart Failure (HF), common CVD conditions ${ }^{8,9}$, present with symptoms such as shortness of breath and reduced exercise tolerance as the disease progresses ${ }^{10-12}$. This suggests that they find it difficult to physically function, such as to carry out activities of daily living.

The World Health Organization (WHO) stated that almost $30 \%$ of global mortality deaths were due to CVDs in 2016, and three-quarter of the CVD-related deaths occur in developing countries each year ${ }^{13}$. Correspondingly, about
$11 \%$ of all mortality cases that accounted to almost $6 \%$ of total global deaths in 2013 were due to CVD in SSA ${ }^{14}$. It is anticipated that by 2030 the prevalence and death rates associated with CVD pandemic will rise by over $70 \%$ in Africa ${ }^{15}$, which is a threat to the health-care resources and economic growth of the continent. Mocumbi claims that CVD attributes to between $7 \%$ and $10 \%$ of total adult hospital admissions in Africa ${ }^{16}$, which lasts approximately 6-80 days in SSA ${ }^{17}$; suggesting a prolonged consumption of health-care resources. Also, this implies that patients are at a risk of acquiring hospital-related infections and suffering from effects of prolonged bedridden such as pressure ulcers and pneumonia. Compared to other continents, literature indicates that more middle-aged patients (aged 53 $\pm 0.4 \mathrm{yrs}$ ) with heart failure are from Africa and have no health $(66 \%)$ and medical (67\%) insurance coverages ${ }^{18}$. Therefore, it is reasonable to postulate that most patients with CVD in the SSA rely on free medical care that is not easily and adequately accessible, and are no longer able to contribute to the development of their countries.

In addition to medication and surgical interventions, Cardiac Rehabilitation (CR) has shown to be an effective 
management strategy for $\mathrm{CVD}^{19}$. Briefly, CR refers to a conservative management approach comprising of exercise, education and counselling therapeutic components, aimed at promoting healthy behaviors and functional independency, and minimizing or eliminating factors that may foster rapid progression of $\mathrm{CVD}^{19}$. The ultimate goal of $\mathrm{CR}$ is to equip patients with self-management skills to be able to attain and sustainably maintain the aforementioned desired objectives ${ }^{19}$. Several existent CR guidelines recommend that all CR components should be delivered comprehensively ${ }^{20-23}$. However, such recommendation would efficiently be implemented in well-resourced CR units available in high income unlike the middle and low income countries whose units are under-resourced. Interestingly, Grace et al. and the WHO suggested CR delivery models for resourceconstrained areas; the models advocate for delivery of any therapeutic component using either home or hospital based approaches ${ }^{24,25}$.

Indeed, literature has shown that Exercise Therapy (ET) can effectively be implemented in isolation of other therapies. For instance, Anderson et al. claimed that exercising led to a reduction in CVD-related deaths (RR 0.74, 95\% CI 0.640.86 ) and risk of hospitalization (RR $0.82,95 \% \mathrm{CI}$ 0.7-0.96) among patients with $\mathrm{CHD}$ at 1 year than not exercising ${ }^{26}$. This suggests that CR improves survival and prevents occurrence of complications associated with hospitalizations. Furthermore, Risom et al. claimed that patients with atrial fibrillation presented with increased maximal oxygen consumption (VO2max) and 6-minute Walking Distance (WKD) by 4ml.kg-1.min-1 (95\%CI 1.4-6ml.kg-1.min-1) and $76 \mathrm{~m}(95 \% \mathrm{CI} 14-138 \mathrm{~m})$ respectively, following ET than not exercising ${ }^{27}$; suggesting that ET is an essential aspect of CR. However, such evidence is from developed countries, where multiple factors such as intellectual capacity of patients and availability of resources also empower them to live healthier than in developing settings.

Unfortunately, countries in SSA are still failing to implement CR despite the modified approaches being suggested. However, little can be gleaned from literature regarding efficacy of the modified CR delivery model in SSA. Establishing such knowledge would assist in motivating for scaling up of the intervention in the region. Therefore, the aims of this study were to identify the benefits of CR treatment components in SSA and to assess if delivery of individual CR treatment modalities should be promoted in this African region.

\section{Methods \\ Study design and eligibility criteria}

This was a systematic review of both clinical trials and retrospective cohort studies, and included both randomized and non-randomized studies that were conducted on people with CVD in SSA. The enrolled studies had to have implemented either ET, education or counselling sessions or a combination of any treatment modalities from the mentioned interventions. Inclusion criteria also demanded that enrolled studies must have measured changes in any of the following variables; mortality and morbidity rates, length of hospitalization, re-hospitalization cases, health care related-costs, quality of life, exercise capacity, functional status, anthropometric measurements, lipid profile, and cardiovascular and respiratory parameters. Studies in other languages other than English were excluded.

\section{Electronic searches}

\section{Sorting and extraction of data}

Overall, reporting of this systematic review followed the PRISMA statement ${ }^{28}$. Two researchers independently extracted data from each article, using a standardized tool that was adapted from $\mathrm{Hart}^{29}$ and was modified using the population, intervention, comparison, outcomes, and study designs (PICOS) concept in relation to the set questions for this review. Thereafter, comparisons and discussions were made, and differences were resolved by another researcher. Quality assessment was done using Downs and Black checklist ${ }^{30}$, and results were interpreted using the following scale: 26-28 excellent, 20-25 good, 15-19 fair and $<14$ poor31. The checklist by Downs and Black was selected because it was designed to analyse quality of methods used for both randomised and non-randomised clinical trials. Also, it is a reliable and valid tool because it had high scores on testretest $(\mathrm{r}=0.88)$, inter-rater $(\mathrm{r}=0.75)$ and internal (KuderRichardson 20 [KR-20]: 0.89) reliability checks ${ }^{30}$.

\section{Presentation of findings}

The changes in the outcomes for each group (control and treated) or from baseline, were expressed as mean change or percent change. The differences in the mean changes between groups were noted to indicate the general effect size of each intervention. Standard deviation (SD), confidence interval (CI) and significance level (p-value) accompanied each mean change. However, some studies did not report either SDs, CIs or P-values, hence not shown in the extracted data; the final outcomes are summarized in a table.

\section{Results}

The literature search identified 1666 studies. Following examination of citations and abstracts, 24 full text articles were reviewed and 10 were included for this review (Figure 1).

\section{Quality assessment of the enrolled studies}

Overall, methods used in 50\% of the studies ${ }^{32-36}$ were rated 'good', $40 \%{ }^{37-40}$ were rated 'fair' and the remainder 41 had a poor rating; statistical power was a challenge across $60 \%$ of the articles. Table 2 illustrates the results of quality assessment of the methods used in the enrolled studies.

\section{Description of enrolled studies}

Three studies were randomised controlled trials ${ }^{32-34}$, two studies were non-randomised controlled trials25,31 and the remainder were uncontrolled trials $\mathrm{s}^{36-40}$. All except on $\mathrm{e}^{38}$ studies were prospectively done, and most of the studies $(60 \%)$ were done in South Africa ${ }^{35-38,40,41}$, followed by Nigeria $(30 \%)^{32-34}$ and only on ${ }^{39}$ was conducted in Benin.

Three studies ${ }^{32,33,40}$ examined the effect of a comprehensive CR that involved resistance and aerobic training plus counselling and education therapies, and two studies ${ }^{36,38}$ analysed the impact of aerobic training and education. Two studies $^{34,41}$ assessed the efficacy of aerobic and resistance training, and three studies ${ }^{35,37,39}$ investigated the effectiveness of implementing aerobic training only.

Studies reported a variety of outcomes including anthropometric ${ }^{32,38-40}$, respiratory ${ }^{32}$, cardiovascular ${ }^{32,33,35,39,40}$, lipid profile and glucose levels $\mathrm{s}^{36,38,40}$, general CVD risk factor profile ${ }^{40}$, quality of life ${ }^{40,41}$, exercise capacity and functional ability $^{32-38,40}$ measures. The dosage of ET ranged widely across studies, with a total of 3 sessions per week each 


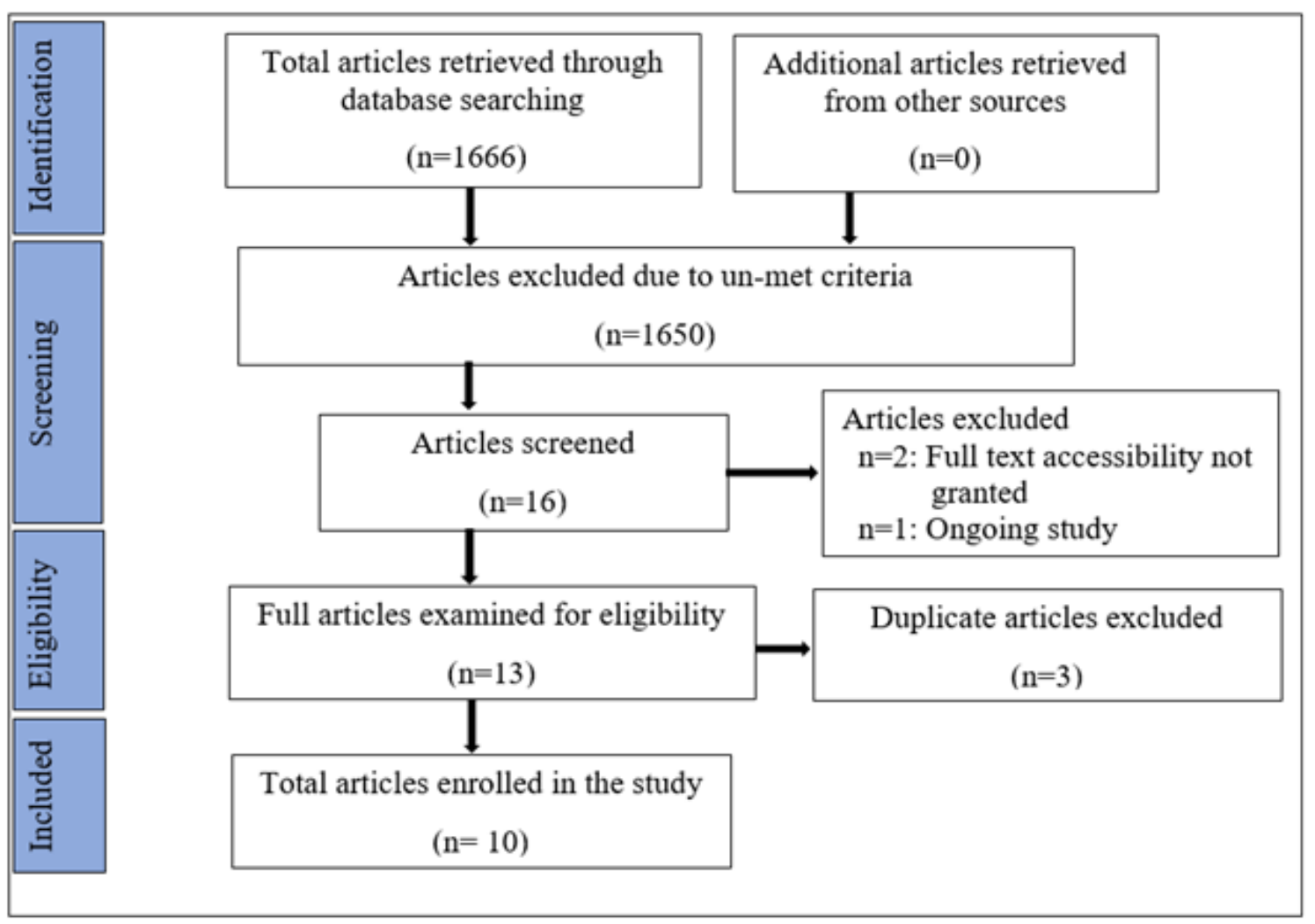

Figure 1. PRISMA Flow Diagram

Table 1. Search strategy generation terms

\begin{tabular}{|c|c|c|c|}
\hline Question & \multicolumn{3}{|c|}{$\begin{array}{l}\text { What could be the possible effects of cardiovascular rehabilitation on clinical outcomes in Sub-Saharan Africa, } \\
\text { which may help Malawi as a nation if the intervention is to be applied in the country? }\end{array}$} \\
\hline Concepts & Cardiovascular Disease & Rehabilitation & Sub-Saharan Africa \\
\hline Key words & $\begin{array}{l}\text {-Cardiovascular disease } \\
\text {-Heart disease } \\
\text {-Cardiac disease } \\
\text {-Cardiopathic } \\
\text {-Myocardial infarction } \\
\text {-Ischemic heart disease } \\
\text {-Coronary artery disease } \\
\text {-Coronary heart disease } \\
\text {-Heart failure } \\
\text {-Heart attack }\end{array}$ & $\begin{array}{l}\text {-Rehab } \\
\text {-Exercises } \\
\text {-Exercise therapy } \\
\text {-Exercise program } \\
\text {-Exercise training } \\
\text {-Education } \\
\text {-Counselling } \\
\text {-Secondary prevention } \\
\text {-Cardiac rehab } \\
\text {-Physical activity } \\
\text {-Physical fitness } \\
\text {-Physical therapy }\end{array}$ & $\begin{array}{l}\text {-Sub-Saharan Africa } \\
\text {-SSA } \\
\text {-South of Sahara } \\
\text {-Tropical Africa } \\
\text {-Central Africa } \\
\text {-Southern Africa } \\
\text {-South East Africa } \\
\text {-Western Africa } \\
\text {-Africa }\end{array}$ \\
\hline STRATEGY & \multicolumn{3}{|c|}{$\begin{array}{l}\text { (("Cardiovascular disease" OR "Heart disease" OR "Coronary heart disease" OR "Coronary artery disease" } \\
\text { OR "Ischaemic heart disease" OR "Myocardial infarction" OR "Heart disease" OR "Cardiopathic" OR "Cardiac } \\
\text { disease" OR "Heart attack") AND (Rehab* OR Exercises OR "Exercise therapy" OR "Exercise training" OR } \\
\text { "Cardiac rehab*” OR Education OR Counselling OR "Secondary prevention" OR "Exercise program*” OR } \\
\text { "Physical activity" OR "Physical fitness" OR "Physical therapy") AND ("Sub-Saharan Africa" OR "Tropical } \\
\text { Africa" OR "Central Africa" OR "Southern Africa" OR "South East Africa" OR "Western Africa" OR Africa)) }\end{array}$} \\
\hline
\end{tabular}


Table 2. Methodological quality assessment outcomes of the enrolled studies

\begin{tabular}{|c|c|c|c|c|c|c|c|}
\hline \multirow[t]{2}{*}{ STUDIES } & \multicolumn{7}{|c|}{ CHECKLIST ITEMS (DOWNS \& BLACK $\left.{ }^{20}\right)$} \\
\hline & \begin{tabular}{|l|} 
Reporting (Total \\
Score[TS]:11)
\end{tabular} & $\begin{array}{l}\text { External } \\
\text { validity } \\
\text { (TS:3) }\end{array}$ & $\begin{array}{l}\text { Internal } \\
\text { validity-bias } \\
\text { (TS:7) }\end{array}$ & $\begin{array}{l}\text { Internal validity- } \\
\text { confounding (selection } \\
\text { bias) (TS:6) }\end{array}$ & $\begin{array}{l}\text { Power } \\
\text { (TS:1) }\end{array}$ & $\begin{array}{l}\text { Total } \\
\text { (TS:28) }\end{array}$ & Interpretation \\
\hline $\begin{array}{l}\text { Rooy \& Coopoo } \\
(2017)\end{array}$ & 8 & 3 & 4 & 2 & 0 & 17 & Fair \\
\hline $\begin{array}{l}\text { Awotidebe et al. } \\
\text { (2016) }\end{array}$ & 10 & 3 & 5 & 6 & 1 & 25 & Good \\
\hline Ajiboye et al. (2015) & 10 & 3 & 5 & 6 & 0 & 24 & Good \\
\hline Ajiboye et al. (2013) & 11 & 3 & 5 & 5 & 0 & 24 & Good \\
\hline $\begin{array}{l}\text { Kpadonou et al. } \\
(2013)\end{array}$ & 8 & 3 & 4 & 3 & 1 & 19 & Fair \\
\hline $\begin{array}{l}\text { Joughin et al. } \\
\text { (1999) }\end{array}$ & 7 & 3 & 5 & 5 & 1 & 21 & Good \\
\hline Digenio et al. (1996) & 9 & 3 & 5 & 2 & 0 & 19 & Fair \\
\hline Morris et al. (1993) & 10 & 3 & 5 & 3 & 1 & 22 & Good \\
\hline Digenio et al. (1991) & 8 & 3 & 5 & 2 & 0 & 18 & Fair \\
\hline $\begin{array}{l}\text { Schomer \&Noakes } \\
\text { (1983) }\end{array}$ & 6 & 3 & 2 & 2 & 0 & 13 & Poor \\
\hline
\end{tabular}

Table 3. Collective summary of results of all enrolled studies

\begin{tabular}{|c|c|c|c|c|}
\hline $\begin{array}{l}\text { Rooy \& } \\
\text { Coopoo } \\
\text { (2017) }\end{array}$ & $\begin{array}{l}\text { Patients with coronary } \\
\text { artery disease that had } \\
\text { undergone surgical } \\
\text { revascularization: } \\
\text { Female: }(n=1) \\
\text { Male: }(n=17) \\
\text { Mean age: } 65.2 \pm 8 Y r s\end{array}$ & $\begin{array}{l}\text { Design: Longitudinal and } \\
\text { experimental cohort study } \\
\text { Intervention: Comprehensive } \\
\text { CR }\end{array}$ & $\begin{array}{l}\text { Cardiovascular } \\
\text { SBP: }-6 \mathrm{mmHg} \text { ( } p=0.001) \\
\text { Exercise capacity and } \\
\text { functional ability } \\
\text { Weekly exercise duration } \\
\text { (WED): } 150 \% \text { ( } p=0.001 \text { ) } \\
\text { Energy expenditure/ } \\
\text { session: } 42 \% \text { ( } p=0.001 \text { ) } \\
\text { Weekly energy expenditure } \\
\text { (WEE): } 57 \% \text { ( } p=0.001 \text { ) } \\
\text { Quality of life } \\
\text { Physical functioning: } \\
13 \%(p=0.001), \text { Social } \\
\text { functioning: } 40 \% \\
\text { ( } p=0.001), \text { Mental } \\
\text { capacity: } 7 \% \text { ( } p=0.002 \text { ) }\end{array}$ & $\begin{array}{l}\text { A comprehensive CR } \\
\text { comprising of both } \\
\text { cardiovascular and } \\
\text { resistance exercises and } \\
\text { counselling or education } \\
\text { therapy is of paramount to } \\
\text { achieving cardioprotective } \\
\text { effect. }\end{array}$ \\
\hline $\begin{array}{l}\text { Awotidebe } \\
\text { et al. (2016) }\end{array}$ & $\begin{array}{l}\text { Patients with chronic heart } \\
\text { failure (CHF): } \\
\text { Intervention Group (IG): } \\
(n=35) \\
\text { Control Group (CG): } \\
(n=35) \\
\text { Mean age } \\
\text { IG:69 } \pm 7 \text { years } \\
\text { CG: } 64 \pm 12 \text { years } \\
\text { Female: ( } n=38) \\
\text { Male: }(n=32)\end{array}$ & $\begin{array}{l}\text { Design: RCT } \\
\text { IG: Aerobic and strength training } \\
\text { CG: Usual medications }\end{array}$ & 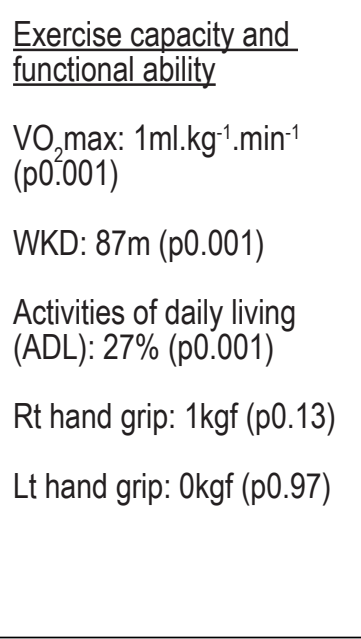 & $\begin{array}{l}\text { Both aerobic and strength } \\
\text { exercises that simulate } \\
\text { daily functional activities } \\
\text { are effective in improving } \\
\text { exercise capacity and ability } \\
\text { of HF patients to perform } \\
\text { ADLs; hence easy to adhere } \\
\text { to }\end{array}$ \\
\hline
\end{tabular}


Table 3 Cont....

\begin{tabular}{|c|c|c|c|c|}
\hline $\begin{array}{l}\text { Ajiboye et } \\
\text { al. (2015) }\end{array}$ & $\begin{array}{l}\text { Patients with Biventricular } \\
\text { chronic heart failure (BVF): } \\
\text { Intervention Group (IG): } \\
(n=28) \\
\text { CG: }(n=23) \\
\text { Mean age: } 54 \pm 2 \text { Yrs } \\
\text { Females: }(n=33) \\
\text { Males: }(n=18)\end{array}$ & $\begin{array}{l}\text { Design: RCT } \\
\text { (IG): Comprehensive CR } \\
\text { (aerobic \& resistance training } \\
\text { plus education or counselling) } \\
\text { Control group (CG): Education } \\
\text { or counselling and usual } \\
\text { medical care }\end{array}$ & $\begin{array}{l}\text { Cardiovascular } \\
\text { Systolic blood pressure } \\
\text { (SBP): -3.6mmHg } \\
\text { ( } p=0.085) \\
\text { Diastolic blood pressure } \\
\text { (DBP): -4mmHg ( } p=0.011) \\
\text { Resting heart rate (RHR): } \\
-6.7 b p m \text { ( } p=0.03) \\
\text { Exercise capacity and } \\
\text { functional ability } \\
\text { Maximal oxygen } \\
\text { consumption (VO max): } \\
2.7 m l . k{ }^{-1} . \text { min }^{-1}\left(p^{2}<0.001\right) \\
\text { Walking distance (WKD): } \\
40.3 m \text { ( } p<0.001) \\
\text { Metabolic equivalents } \\
\text { (METS): } 2.5 \text { ( } p=0.001) \\
\text { Rating of perceived } \\
\text { exertion (RPE): }-1.9 \\
\text { ( } p=0.001)\end{array}$ & $\begin{array}{l}\text { A comprehensive CR is } \\
\text { effective and should be } \\
\text { incorporated in the usual } \\
\text { care of HF patients after } \\
\text { holistic patient assessment } \\
\text { and risk stratification }\end{array}$ \\
\hline $\begin{array}{l}\text { Ajiboye et } \\
\text { al. (2013) }\end{array}$ & $\begin{array}{l}\text { Patients with biventricular } \\
\text { heart failure (BHF): } \\
\text { IG: }(n=17) \\
\text { CG: }(n=15) \\
\text { Mean age } \\
\text { IG: } 54 \pm 2.2 \text { years } \\
\text { CG: } 53.7 \pm 3 \text { years } \\
\text { Female: }(n=15) \\
\text { Male: }(n=17)\end{array}$ & $\begin{array}{l}\text { Design: RCT } \\
\text { IG: Comprehensive CR } \\
\text { CG: Education or counselling } \\
\text { plus usual medications }\end{array}$ & 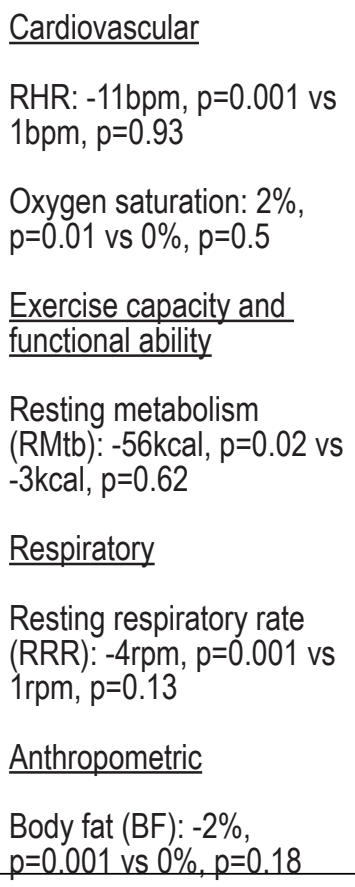 & $\begin{array}{l}\text { Structured exertion improves } \\
\text { resting breathing and pulse } \\
\text { rates, oxygen saturation } \\
\text { and body fat percentage } \\
\text { among Nigerians chronically } \\
\text { suffering from HF }\end{array}$ \\
\hline $\begin{array}{l}\text { Kpadonou } \\
\text { et al. (2013) }\end{array}$ & $\begin{array}{l}\text { Patients with compensated } \\
\text { heart diseases: Female: } \\
(n=7) \\
\text { Male: }(n=20) \text {, Mean age: } \\
43 \pm 9.7 \text { Yrs }\end{array}$ & $\begin{array}{l}\text { Design: Prospective descriptive } \\
\text { study } \\
\text { Intervention: Aerobic exercise } \\
\text { training }\end{array}$ & $\begin{array}{l}\text { Cardiovascular } \\
\text { RHR: }-17 \mathrm{bpm}, p=0.001, \\
\text { SBP: }-14 \mathrm{mmHg}, p=0.001, \\
\text { DBP: }-6 \mathrm{mmHg}, p=0.001 \\
\text { Anthropometric: Body } \\
\text { mass index (BMl): }-2 \mathrm{~kg} \cdot \mathrm{m}- \\
{ }^{2}, p=0.2\end{array}$ & $\begin{array}{l}\text { Poorly resourced areas can } \\
\text { use 'little-difficult' exercise } \\
\text { intensity using Borg scale } \\
\text { effectively. }\end{array}$ \\
\hline
\end{tabular}


Table 3 Cont....

\begin{tabular}{|c|c|c|c|c|}
\hline $\begin{array}{l}\text { Joughin et } \\
\text { al. (1999) }\end{array}$ & $\begin{array}{l}\text { Patients with CAD; } \\
\text { IG: }(n=93) \\
\text { CG: }(n=18) \\
\text { Female: }(n=9) \\
\text { Male: }(n=102) \\
\text { Mean age } \\
\text { IG: } 57.3 \pm 11 \text { years } \\
\text { CG: } 59.4 \pm 11 \text { years }\end{array}$ & $\begin{array}{l}\text { Design: Prospective NRCT } \\
\text { IG: Aerobic exercise training } \\
\text { CG: Aerobic exercise training } \\
<10 \% \text { of the total dosage }\end{array}$ & $\begin{array}{l}\text { Cardiovascular } \\
\text { RHR: }-3.6 \mathrm{bpm}, p<0.05 \text { vs } \\
\text { Obpm, } p>0.05 \\
\text { SBP: }-6 \mathrm{mmHg}, p<0.05 \text { vs } \\
-8 \mathrm{mmHg}, p>0.05 \\
\text { HRmax: } 4 \mathrm{bpm}, p<0.05 \text { vs } \\
1 \mathrm{bpm}, p>0.05 \\
\text { Exercise capacity and } \\
\text { functional ability } \\
\text { vo max: } 2.7 \mathrm{~mL} . \mathrm{kg}^{-1} \cdot \mathrm{min}^{-1} \text {, } \\
p=0.0001 \mathrm{vs} 1.2 \mathrm{~mL}^{-\mathrm{kg}^{-1}} . \\
\text { min }{ }^{-1}, p>0.05\end{array}$ & $\begin{array}{l}\text { Cardiac rehabilitation } \\
\text { is effective and longer } \\
\text { programmes should be } \\
\text { emphasised to promote and } \\
\text { enhance healthy behavior } \\
\text { modifications in a long run }\end{array}$ \\
\hline $\begin{array}{l}\text { Digenio et } \\
\text { al. (1996) }\end{array}$ & $\begin{array}{l}\text { Patients with Ml and left } \\
\text { ventricular dysfunction; } \\
\text { Total sample size: }(n=28) \\
\text { Mean age: } 63.5 \pm 7.5 \mathrm{Yrs}\end{array}$ & $\begin{array}{l}\text { Design: Intervention, before and } \\
\text { after trial } \\
\text { Intervention: Aerobic exercise } \\
\text { training }\end{array}$ & $\begin{array}{l}\text { Cardiovascular } \\
\text { RHR: }-7 \mathrm{bpm}(\mathrm{p}=0.001) \\
\text { Exercise capacity and } \\
\text { functional ability } \\
\text { VO }{ }_{2} \text { max: } 12.4 \%(p<0.05) \\
\text { Endurance: } 32.8 \% \\
(p=0.001) \\
\text { Ejection fraction } \\
\text { Resting ejection fraction } \\
\text { (REF): } 3.1 \%(p<0.05) \\
\text { Exercise ejection fraction } \\
\text { (EEF): } 2.7 \%(p=0.11)\end{array}$ & $\begin{array}{l}\text { Patients with severe HF can } \\
\text { safely exercise and achieve } \\
\text { functional independency with } \\
\text { specially designed programs. }\end{array}$ \\
\hline $\begin{array}{l}\text { Morris et al. } \\
\text { (1993) }\end{array}$ & $\begin{array}{l}\text { Patients with different } \\
\text { cardiac conditions such as } \\
\text { CAD and Atrial fibrillation } \\
\text { Age range: } 31-79 Y \text { rs } \\
\text { Female: }(n=13) \\
\text { Male: }(n=129)\end{array}$ & $\begin{array}{l}\text { Design: Experimental trial, with } \\
\text { before and after intervention } \\
\text { analytical approach } \\
\text { Intervention: Aerobic training } \\
\text { and education or counselling } \\
\text { therapy }\end{array}$ & $\begin{array}{l}\frac{\text { Exercise capacity and }}{\text { functional ability }} \\
\text { VO max: } 15 \%(p=0.001) \\
\text { Ventilatory threshold (VT): } \\
14 \% \text { ( } p=0.001) \\
\text { Lipid profile and glucose } \\
\underline{\text { levels }} \\
\text { High density lipoprotein } \\
\text { (HDL): } 7 \%(p=0.001), \\
\text { ApoA: } 2.73 \%(p=0.02), \\
\text { Total CH/HDL: }-9 \% \\
\text { ( } p=0.02) \\
\text { ApoA/ApoB: }-9.4 \% \\
(p=0.01)\end{array}$ & $\begin{array}{l}\text { CR effectively modifies lipid } \\
\text { profile, thereby assisting in } \\
\text { either lessening the severity } \\
\text { of CVD or preventing } \\
\text { occurrence of further cardiac } \\
\text { events }\end{array}$ \\
\hline
\end{tabular}


lasting 30-60 minutes, intensity of 40-90\% maximal heart rate (HRmax) to $70 \% \mathrm{VO}_{2}$ max to $11-13$ Rating of Perceived Exertion (RPE) for endurance exercises, and $50-75 \%$ of 1 repetition maximum (1RM) for strengthening exercises, over a period of 2-18 months. The interventions were facilitated and implemented in clinical supervised settings. Most of the studies $(\mathrm{n}=7)$ had sample sizes ranging from 16-70, and only Joughin et al. ${ }^{35}$, Morris et al. ${ }^{36}$ and Digenio et al. ${ }^{38}$ had relatively large sizes of 111,142 and 387 respectively. The participants' age ranged from 20-89 years.

Statistically, the significance level of outcomes was set at $<0.05$ across all studies. Two studies ${ }^{34,40}$ adjusted the significance level by applying Bonferroni adjustment to correct for errors that could be encountered due to conduction of multiple tests on the same participants ${ }^{42}$. The remaining eight studies did not report usage of the correction factor regardless of conducting multiple comparisons on the same participants. The significance tests were largely reported for the change difference between the pre- and post-intervention unlike control and intervention change size. Quality of life was measured subjectively by varying assessment tools and all other outcomes were objectively measured using standardized tools.

\section{Efficiency of the cardiac rebabilitation treatment components}

Briefly, the enrolled studies examined exercise, education and psycho therapeutic components of CR. However, education and psycho therapies were mostly offered through a comprehensive delivery approach. Additionally, most of the studies put more emphasis on exercise than education component; only Rooy and $\mathrm{Coopoo}^{40}$, Morris et al ${ }^{36}$ and Digenio et al. ${ }^{38}$ incorporated dietary therapy in the education component. Table 3 shows the summary of results from the enrolled studies.

\section{Comprehensive cardiac rehabilitation}

Ajiboye et al. randomized patients with BVF into two groups; (i) the IG participated in both aerobic and resistance exercise training plus education and counselling sessions, and (ii) the CG attended education sessions ${ }^{33}$. All patients were on appropriate medications as prescribed by their cardiologists. While RHR, RRR and BF significantly reduced by $11 \mathrm{bpm}$ $(p<0.001), 4 b p m(p<0.001)$ and $2 \%(p<0.001)$ respectively among the IG, the parameters barely changed in the $C G$ $(\mathrm{p}<0.9 ; \mathrm{p}<0.13 ; \mathrm{p}<0.18$ respectively). Additionally, oxygen saturation levels rose by $2 \%(p<0.01)$ in the IG and did not change in the CG $(\mathrm{p}>0.5)$. There were non-significant differences in both SBP and DBP (All: $\mathrm{p}>0.05$ ).

In 2015, Ajiboye et al. also randomized patients with BVF into IG and CG; the former received a comprehensive CR and the latter attended education therapy ${ }^{32}$. The VO2max, WKC and METs increased significantly by $2.7 \mathrm{ml} . \mathrm{kg}-1 . \mathrm{min}-$ $1(\mathrm{p}<0.001), 40.3 \mathrm{~m}(\mathrm{p}<0.001)$ and $2.5(\mathrm{p}<0.001)$ in favor of IG than CG. Compared to CG, RHR, RPE and DBP significantly decreased by $7 \mathrm{bpm}(\mathrm{p}<0.03), 2(\mathrm{p}<0.001)$ and $4 \mathrm{mmHg}(\mathrm{p}<0.011)$. No significant difference in SBP was observed $(\mathrm{p}<0.085)$.

A longitudinal and experimental cohort study by Rooy and Coopoo examined the effectiveness of a holistic CR intervention on patients with $\mathrm{CHD}$ who had undergone coronary artery bypass grafting $(\mathrm{CABG})^{40}$. Significant reductions were observed in SBP $(-6 \mathrm{mmHg}, \mathrm{p}<0.001)$, BF $(-10 \%, \mathrm{p}<0.001)$, modifiable $(-19 \%, \mathrm{p}<0.001)$ and total
$(-12 \%, \mathrm{p}<0.001)$ CVD risk factors. Furthermore, weekly energy expenditure and duration of exertion increased by $57 \%(p<0.001)$ and 3.3hours $(p<0.001)$. Physical, social and mental aspects of quality of life also improved significantly by $13 \% \quad(p<0.001), 40 \% \quad(p<0.001)$ and $7 \% \quad(p<0.002)$ respectively. The RHR, BW, BMI, waist circumference, walking capacity, cholesterol, blood glucose and DBP did not change (All: $\mathrm{p}>0.01$ ).

\section{Aerobic and resistance training}

Awotidebe et al. evaluated the effectiveness of CR constituting aerobic and resistance type of exercises on patients who were being medically managed for $\mathrm{CHF}^{34}$. The ET involved walking, jogging and calisthenics that constituted biceps and triceps curls. Patients were randomized into IG and CG; the latter did not receive anything except the medications prescribed by their cardiologists. Compared to the CG, participants in IG showed significant improvements in the VO2max (1mL.kg-1.min-1, $\mathrm{p}<0.001)$, capacities to perform activities of daily living $(27 \%, \mathrm{p}<0.001)$ and walk $(87 \mathrm{~m}$, $\mathrm{p}<0.001)$. No significant changes in both right- and lefthand grip strength existed between the groups (All: $\mathrm{p}>0.01$ ). In 1982, Schomer and Noakes investigated the impact of resistance and aerobic exercise training on quality of life of cardiac patients41. Patients were not randomly enrolled into the intervention, and those who did not continue with exercise training for more than a month constituted a comparison group. The ET intervention was consisted of jogging, walking and light calisthenics. Significant 6\% $(p<0.01)$ and $12 \%(p<0.05)$ reductions in depression and anxiety respectively favored the IG than CG. Compared to CG, participants in IG were emotionally stable by $12.5 \%$ $(p<0.01)$ and showed $11 \%(p<0.01)$ significant increment in the capacity to imagine things.

\section{Aerobic exercise training and education}

Retrospectively, Digenio et al. examined the efficacy of implementing cardiovascular type of exercise and educating cardiac patients the need for lifestyle modification and healthy living ${ }^{38}$. Largely, the participants included patients with CHD who had undergone CABG. The baseline findings were compared to the post-intervention results to measure the effect size of the therapy. Participants with more than $80 \%$ adherence to the intervention showed significant increment in VO2max by $5 \mathrm{~mL} . \mathrm{kg}-1 . \mathrm{min}-1$ ( $\mathrm{p}<0.01)$ compared to $40 \%$ adherence rate $(\mathrm{p}>0.05)$. Furthermore, the former group presented with $2 \mathrm{~kg}(\mathrm{p}<0.01)$ significant reduction in $\mathrm{BW}$ than the latter $(p>0.05)$. No significant change in BF was observed between the groups ( $p>0.05)$.

In an experimental trial, Morris et al. studied effectiveness of aerobic exercise and education components of CR intervention on patients with various types of cardiac conditions $^{36}$. The post-intervention measurements were compared to the baseline findings to detect the effect size of the therapy. The intervention led to significant increases in $\mathrm{VO} 2 \max (14.9 \%, \mathrm{p}<0.001)$, ventilatory threshold $(13.8 \%$, $\mathrm{p}<0.001)$, HDL $(7 \%, \mathrm{p}=0.001)$ and Apo A / Apo B (9\%, $\mathrm{p}<0.01)$. Furthermore, significant reduction in the ratio between total cholesterol and HDL $(-9 \%, \mathrm{p}<0.02)$ was associated with the therapy. Non-significant changes in total cholesterol $(p<0.37)$, LDL $(p<0.76)$ and Triglycerides $(p<0.30)$ were also observed.

\section{Aerobic training}


Joughin et al. evaluated the efficacy of cardiovascular exercises on patients with $\mathrm{CAD}^{35}$. The participants were non-randomly selected, and patients that complied less to the intervention $(\leq 10 \%)$ formed a comparison group. Compared to $C G$, the IG presented with significant improvements in $\mathrm{VO}_{2} \max (2.7 \mathrm{~mL} . \mathrm{kg}-1 . \mathrm{min}-1, \mathrm{p}=0.001$ vs $1 \mathrm{~mL} . \mathrm{kg}-1 . \mathrm{min}-$ $1, \mathrm{p}>0.05$ ), endurance (2minutes, $\mathrm{p}<0.001$ vs 0.2 minutes, $\mathrm{p}>0.05)$, HRmax (4bpm, $\mathrm{p}<0.05$ vs $1 \mathrm{bpm}, \mathrm{p}>0.05)$, SBP $(-6 \mathrm{mmHg}, \mathrm{p}<0.05 \mathrm{vs}-8 \mathrm{mmHg}, \mathrm{p}>0.05)$ and RHR (-3.6bpm, $\mathrm{p}<0.05$ vs $0 \mathrm{bpm}, \mathrm{p}>0.05)$.

In 1996, Digenio et al. analyzed the impact of aerobic training on patients with CHD and left ventricular failure ${ }^{37}$. Comparisons between baseline and post-therapy findings were made to establish the effect size. Aerobic training reduced RHR significantly by $7 \mathrm{bpm}(\mathrm{p}<0.001)$ and led to $33 \% \quad(p=0.001)$ and $12 \%(p<0.05)$ significant increases in endurance and $\mathrm{VO}_{2} \max$ respectively. Furthermore, the therapy led to $3 \%(\mathrm{p}<0.05)$ increased ejection fraction at rest. The ejection fraction during exercise did not change significantly $(\mathrm{p}<0.11)$.

Kpadonou et al. examined the effect of aerobic exercise on patients with compensated cardiac diseases and employed use of RPE to prescribe and monitor ET ${ }^{39}$. The pre-and post-intervention findings were analyzed to deduce the effect size. Significantly, the treatment resulted in $17 \mathrm{bpm}$ $(p<0.001), 14 \mathrm{mmHg} \quad(p<0.001)$ and $6 \mathrm{mmHg} \quad(p<0.001)$ reductions in RHR, SBP and DBP respectively. The BMI did not change significantly $(\mathrm{p}<0.2)$.

\section{Discussion}

This systematic review shows evidence supporting the efficacy of CR treatment modalities in SSA. Although Grace et al. $^{24}$ and WHO25 recommend implementation of any CR treatment component in resource-constrained areas, this review found evidence supporting delivery of ET component with or without education and (or) counselling therapies, and not independent delivery of psycho- or education therapies without ET.

\section{Holistic cardiac rehabilitation delivery approach}

According to Ajiboye et al. ${ }^{32}$, comprehensive delivery of CR led to an increase in exertion and walking capacities by about 3 METs and $40 \mathrm{~m}$ respectively ${ }^{32}$. Similarly, Rooy and Coopoo reported that $31 \%$ increase in walking ability was associated with comprehensive $\mathrm{CR}^{40}$. This suggests that holistic delivery of CR aids in improving the patients' functional capacity. Correspondingly, Chaves et al. claimed that a holistic CR intervention in Brazil resulted in increased walking capacity by $76 \mathrm{~m}^{43}$. Although this improvement is greater than the one reported by Ajiboye et al..$^{32}$, the two differed in the dosage of exercise; hence the possibility of the difference in the effect size. Nevertheless, Shoemaker, Curtis, Vangsness and Dickinson claimed that minimum of $45 \mathrm{~m}$ increase in walking capacity has a significant clinical effect ${ }^{44}$. Also, the American Thoracic Society (ATS) guidelines recommend a $43 \mathrm{~m}$ increment as a minimal value with effect ${ }^{45}$. Arguably, it is reasonable to postulate that the results from this review are in a positive direction. However, exercise prescription should be done cautiously to maximize achievement of desirable outcomes.

Holistic delivery of $\mathrm{CR}$ also attributed to improvements in physical, social and mental components of quality of life of patients by $13 \%, 40 \%$ and $7 \%$ respectively ${ }^{40}$. Similarly, Choo et al. reported that holistic delivery of CR significantly increased physical and mental aspects of quality of life by almost $6(p<0.001)$ and $2(p<0.001)$ scores respectively, and reduced depression scores by $1.4(\mathrm{p}<0.001)^{46}$. This entails that the holistic CR delivery approach improves all aspects of general well-being of an individual, which is one of the fundamental outcomes of $\mathrm{CR}$ as stipulated in the BACPR guidelines ${ }^{19}$.

\section{Modified cardiac rebabilitation delivery approach}

Evidence from Awotidebe et al. and Schomer and Noakes shows that delivery of aerobic and strength exercise training through walking, jogging and calisthenics is beneficial in under-resourced areas ${ }^{34,41}$. Firstly, the capacity to perform ADLs and to walk improved by $27 \%$ and $87 \mathrm{~m}$ respectively ${ }^{34}$. Recently, Mohammed and Shabana also associated a $78 \mathrm{~m}$ $(p<0.001)$ significant change in walking capacity to aerobic training combined with calisthenics and education therapy ${ }^{47}$. The preceding study was conducted in Egypt, a developing country in Africa, and made use of treadmill to deliver aerobic ET; suggesting that use of naturally existing mode of exercises such as walking, as used by the two enrolled studies $^{34,41}$, is equally effective. Similarly, Shabani, Gaeini, Nikoo, Nikbackt and Sadegifar claimed approximately 49\% $(p<0.001)$ and $181 \mathrm{~m}(p<0.001)$ increases in endurance and walking distance respectively ${ }^{48}$. This further adds on to the robust evidence that supports incorporation of strength training to cardiovascular exercises, both of which are aspects of an exercise component of CR. Secondly, both anxiety and depression reduced by $12 \%$ and $6 \%$ respectively ${ }^{41}$. Also, imaginativeness and mood stability increased by $11 \%$ and $13 \%$ respectively ${ }^{41}$; suggesting that developing countries in SSA can effectively deliver CR by using readily available modes of exercises that do not require equipment. It is also reasonable to postulate that use of locally made materials in SSA such as sand bags instead of dumb bells for strength training, as Grace et al. ${ }^{24}$ recommends, could effectively assist in delivering both resistance and aerobic exercise and equally attribute to improvements in general well-being of cardiac patients.

Interestingly, delivery of aerobic type of exercise alone led to 4bpm and $6 \mathrm{mmHg}$ reductions in RHR and SBP respectively, and $4 \mathrm{bpmincrease}$ in the peak $\mathrm{HR}^{35}$. Correspondingly, Rashidi, Salehian and Vaezi, claimed almost $3 \mathrm{mmHg}(\mathrm{p}<0.001)$ and $4 \mathrm{bpm}$ reductions in SBP and RHR respectively ${ }^{49}$. Additionally, Rashidi et al. claimed that time taken to reach $85 \%$ of the peak HR increased significantly by almost 1 and half minutes $(p<0.001)^{49}$. This entails that cardiovascular exercises aid in improving exercise tolerance and modulation of the sympathetic regulation of the impaired cardiac function. Likewise, aerobic training monitored using RPE approach, a costless and widely available tool, yielded remarkable reductions in SBP, DBP and RHR by $14 \mathrm{mmHg}, 6 \mathrm{mmHg}$ and $17 \mathrm{bpm}$ respectively ${ }^{39}$. This presupposes that resourceconstrained countries can safely and effectively implement ET. Interestingly, Tsai et al. and Eston and Connoly clearly indicates that use of RPE to prescribe and guide exercise intensity is not influenced by use of any type of medication or exposure to any environment ${ }^{50,51}$. Therefore, this implies that countries in SSA can implement ET effectively without having to purchase exercise monitoring equipment, and patients may be allowed to exercise safely at home without Physiotherapists' supervision. 


\section{Limitations and strengths}

The most prominent strength of this systematic review is that it is the first to analyze the benefits of CR treatment modalities in SSA. Additionally, an extensive strategy was employed in the search for the enrolled studies. However, the analysis in this study was limited with (i) small sample sizes (ii) varying methodologies (iii) lack of statistical power, (iv) inability to adjust for type 1 error across the studies, and (v) limited time to reach out to and get feedback, that would necessitate a possible meta-analysis, from some authors of the enrolled articles; which eventually affect drawing of conclusions. Also, articles not in English and whose full texts could not be accessed were excluded, hence possibility of excluding relevant information. Further investigations (i) with relatively larger sample sizes and appropriate methodologies, and (ii) that also assess education and counselling components of CR and examine clinical outcomes such as rates of mortality and hospitalization should be conducted to facilitate a possible meta-analysis. Nevertheless, medical professionals and policy makers involved in CVD management and secondary prevention care in SSA should consider incorporating CR in their CVD management protocols.

\section{Conclusion}

In summary, the findings from this systematic review indicate that both modified and comprehensive CR delivery approaches are utilized in SSA, and are all beneficial. None of the studies delivered psycho- and(or) education therapies without ET, making it difficult to isolate the benefits of psychotherapy or education therapy. Nevertheless, positive changes in exercise tolerance capacity, quality of life and cardio-respiratory parameters such as BP and HR were identified in this systematic review, and were associated with either ET or ET delivered together with psychotherapy and (or) education therapy. Therefore, countries in SSA may adopt the modified approach of implementing CR, if they cannot afford a comprehensive intervention, by delivering ET component with or without either psychotherapy or education. Delivery of ET component in SSA may employ use of locally available resources, and costless-user friendly exercise monitoring tools such as RPE to promote sustainability and usability of the service and enable patients to safely exercise at home without physiotherapists' supervision respectively. Further studies should be done to evaluate effectiveness of psycho- and education therapies in SSA, by offering each intervention without ET component. Future research should also examine efficacy and safety of using home versus hospital based CR approaches.

\section{What is known on this topic}

- CVD pandemic is exceedingly growing in Sub-Saharan Africa

- African countries have not yet intensely integrated CR intervention in the management of CVD

- CR models for resource-constrained areas advocate for use of readily available resources to implement any CR treatment modality

\section{What this study adds}

- Exercise modality can be offered, in isolation of other CR components in SSA

\section{Competing interest}

The authors declare no competing interest.

\section{References}

1. World Health Organization (WHO). Cardiovascular diseases (CVDs) [Internet]. 2019 [cited 2019 Mar 29]. Available from: https://www.who. int/news-room/fact-sheets/detail/cardiovascular-diseases-(cvds)

2. O'Donnell CJ, Elosua R. Cardiovascular Risk Factors. Insights From Framingham Heart Study. Rev Española Cardiol (English Ed. 2008 Mar 1;61(3):299-310.

3. Faber J, Wingerter A, Neu MA, Henninger N, Eckerle S, Münzel T, et al. Burden of cardiovascular risk factors and cardiovascular disease in childhood cancer survivors: data from the German CVSS-study. Eur Heart J. 2018 May 1;39(17):1555-62.

4. Chiesa S, Farmaki E, Zacharia E, Tousoulis D, Charakida M. Lifestyle Choices, Risk Factors, and Cardiovascular Disease. Cardiovasc Dis Genet Susceptibility, Environ Factors their Interact. 2016 Jan 1;97-118.

5. Fullerton DG, Bruce N, Gordon SB. Indoor air pollution from biomass fuel smoke is a major health concern in the developing world. Trans R Soc Trop Med Hyg. 2008 Sep;102(9):843.

6. Young F, Critchley JA, Johnstone LK, Unwin NC. A review of co-morbidity between infectious and chronic disease in Sub Saharan Africa: TB and Diabetes Mellitus, HIV and Metabolic Syndrome, and the impact of globalization. Glob Heal 2009 51. 2009 Sep 14;5(1):1-9.

7. Sutherland K. Evidence, Bridging the quality gap: Heart Failure. London; 2010.

8. Rahimi K, Lam CSP, Steinhubl S. Cardiovascular disease and multimorbidity: A call for interdisciplinary research and personalized cardiovascular care. PLOS Med. 2018 Mar 1;15(3):e1002545.

9. Prabhakaran D, Jeemon P, Roy A. Cardiovascular Diseases in India: Current Epidemiology and Future Directions. Circulation. 2016 Apr 19;133(16):1605-20.

10. Lu L, Liu M, Sun R, Zheng Y, Zhang P. Myocardial Infarction: Symptoms and Treatments. Cell Biochem Biophys. 2015 Jul 1;72(3):865-7.

11. Taylor CJ, Rutten FH, Brouwer JR, Hobbs FR. Practical guidance on heart failure diagnosis and management in primary care: recent EPCCS recommendations. Br J Gen Pract. 2017 Jul 1;67(660):326.

12. Mentzer GG, Auseon AJ. Exercise capacity in chronic heart failure. US Cardiol. 2012;9(1):57-60.

13. World Health Organization (WHO). Cardiovascular diseases (CVDs) update [Internet]. [cited 2019 Mar 12]. Available from: https:// www.who.int/news-room/fact-sheets/detail/cardiovascular-diseases(cvds)

14. Roth GA, Forouzanfar MH, Moran AE, et al. Demographic and Epidemiologic Drivers of Global Cardiovascular Mortality. http:// dx.doi.org/101056/NEJMoa1406656. 2015 Apr 1;372(14):1333-41.

15. Onen C. Epidemiology of ischaemic heart disease in sub-Saharan Africa. Cardiovasc J Afr. 2013 Mar;24(2):34-42.

16. Mocumbi AO. Lack of focus on cardiovascular disease in subSaharan Africa. Cardiovasc Diagn Ther. 2012;2(1):74.

17. Chikafu H, Chimbari M. Cardiovascular Disease Healthcare Utilization in Sub-Saharan Africa: A Scoping Review. Int J Environ Res Public Health. 2019 Jan 1;16(3).

18. Dokainish H, Teo K, Zhu J, et al. Heart Failure in Africa, Asia, the Middle East and South America: The INTER-CHF study. Int J Cardiol. 2016 Feb 1;204:133-41.

19. British Association for Cardiovascular Prevention and Rehabilitation (BACPR). The Six Core Components for Cardiovascular Disease Prevention and Rehabilitation.

20. Stone J, Arthur H. Canadian guidelines for cardiac rehabilitation and cardiovascular disease prevention, second edition, 2004: executive summary. Can J Cardiol. 2005 Oct 1;21 Suppl D(12 SUPPL. D):3D- 
19D.

21. Pavy B, Liou M, Vergès-Patois B, et al. French Society of Cardiology guidelines for cardiac rehabilitation in adults. Arch Cardiovasc Dis. 2012;105(5):309-28.

22. Irish Association of Cardiac Rehabilitation (IACR). Guidelines for Cardiac Rehabilitation [Internet]. [cited 2021 Sep 11]. Available from: https://iacronline.ie/guidelines.php

23. American Association of Cardiovascular \& Pulmonary Rehabilitation. Guidelines for cardiac rehabilitation and secondary prevention programs. 2004;280.

24. Grace S, Turk-Adawi K, Contractor A, et al. Cardiac rehabilitation delivery model for low-resource settings. Heart. 2016 Sep 1;102(18):1449-55.

25. World Health Organization (WHO). Rehabilitation after Cardiovascular diseases, with special emphasis on developing countries [Internet]. Report of a WHO expert Committee. 1993 [cited 2021 Sep 10]. p. 1-75. Available from: https://apps.who.int/iris/bitstream/ handle/10665/38455/WHO_TRS_831.pdf?sequence=1\&isAllowed=y

26. Anderson L, Oldridge O, Thompson D, et al. Exercise-Based Cardiac Rehabilitation for Coronary Heart Disease: Cochrane Systematic Review and Meta-Analysis. J Am Coll Cardiol. 2016 Jan 5;67(1):1-12.

27. Risom S, Zwisler A, Johansen P, et al. Exercise-based cardiac rehabilitation for adults with atrial fibrillation. Cochrane database Syst Rev. 2017 Feb 9;2(2).

28. Moher D, Liberati A, Tetzlaff J, Altman DG, Group TP. Preferred Reporting Items for Systematic Reviews and Meta-Analyses: The PRISMA Statement. PLOS Med. 2009 Jul;6(7):e1000097.

29. Hart S. The effects of exercise on body mass and body composition in postmenopausal breast cancer survivors: A sytematic review. 2012;

30. Downs S, Black N. The feasibility of creating a checklist for the assessment of the methodological quality both of randomised and non-randomised studies of health care interventions. J Epidemiol Community Health. 1998;52(6):377-84.

31. Hooper P, Jutai J, Strong G, Russell-Minda E. Age-related macular degeneration and low-vision rehabilitation: a systematic review. Can J Ophthalmol. 2008;43(2):180-7.

32. Ajiboye OA, Anigbogu CN, Ajuluchukwu JN, Jaja SI. Exercise training improves functional walking capacity and activity level of Nigerians with chronic biventricular heart failure. Hong Kong Physiother J. 2015 Jun 1;33(1):42-9.

33. Ajiboye O, Anigbogu C, Ajuluchukwu J, Jaja S. Therapeutic Effects of Exercise Training On Selected Cardio-Pulmonary Parameters and Body Composition of Nigerians with Chronic Heart Failure (A Preliminary Study) - PubMed. Nig Q J Hosp Med. 2013;23(4):295-301.

34. Awotidebe TO, Adedoyin RA, Balogun MO, et al. Effects of Cardiac Rehabilitation Exercise Protocols on Physical Function in Patients with Chronic Heart Failure: An Experience from a Resource Constraint Nation. Int J Clin Med. 2016 Aug 3;7(8):547-57.

35. Joughin H, Digenio A, Daly L, Kgare E. Physiological benefits of a prolonged moderate-intensity endurance training programme in patients with coronary artery disease - PubMed. S Afr Med J. 1999;89(5):54550 .

36. Morris R, Digenio A, Padyachee G, Kinnear B. The effect of a 6-month cardiac rehabilitation programme on serum lipoproteins and apoproteins A1 and B and lipoprotein a - PubMed. S Afr Med J. 1993;83(5):315-8.
37. Digenio A, Cantor A, Noakes T, Cloete L, Mavunda D, Esser J. Is severe left ventricular dysfunction a contraindication to participation in an exercise rehabilitation programme? - PubMed. S Afr Med J. 1996 Sep;86(9):1106-9.

38. Digenio AG, Sim JGM, Krige K, et al. The Johannesburg cardiac rehabilitation programme. South African Med J. 1991 Jun 23;79(2):1837.

39. Kpadonou T, Fiogbe E, Datie A, et al. Preliminary Results of a Cardiac Rehabilitation Program in Patients with Compensated Heart Diseases in Sub-Saharan Africa (Benin): A Pilot Study. Int J Phys Med Rehabil Kpadonou. 2013 Oct 7;1:7.

40. Rooy L van, Coopoo Y. Physical activity and lifestyle modification in the reduction of cardiovascular disease risk in coronary artery bypass graft patients. African J Phys Act Heal Sci. 2017 Jul 17;23(2):336-53.

41. Schomer H, Noakes T. The psychological effect of exercise training on patients after a myocardial infarction. A pilot study. S Afr Med J. 1983;64(13):473-5.

42. Kim M, Mallory C. Statistics for evidence-based practice in nursing. 2nd ed. Jones \& Bartlett Learning: Burlington; 2014. 35-210 p.

43. Chaves G, Ghisi G, Grace S, Oh P, Ribeiro A, Britto R. Effects of comprehensive cardiac rehabilitation on functional capacity in a middle-income country: a randomised controlled trial. Heart. 2019 Mar 1;105(5):406-13.

44. Shoemaker MJ, Curtis AB, Vangsnes E, Dickinson MG. Triangulating Clinically Meaningful Change in the Six-minute Walk Test in Individuals with Chronic Heart Failure: A Systematic Review. Cardiopulm Phys Ther J. 2012 Sep;23(3):5.

45. Crapo RO, Casaburi R, Coates AL, et al. ATS statement: Guidelines for the six-minute walk test. Am J Respir Crit Care Med. 2002 Jul 1;166(1):111-7.

46. Choo CC, Chew PKH, Lai S-M, et al. Effect of Cardiac Rehabilitation on Quality of Life, Depression and Anxiety in Asian Patients. Int J Environ Res Public Health. 2018 Jun 1;15(6).

47. Mohammed HG, Shabana AM. Effect of cardiac rehabilitation on cardiovascular risk factors in chronic heart failure patients. Egypt Hear J. 2018 Jun 1;70(2):77.

48. Shabani R, Gaeini AA, Nikoo MR, Nikbackt H, Sadegifar M. Effect of Cardiac Rehabilitation Program on Exercise Capacity in Women Undergoing Coronary Artery Bypass Graft in Hamadan-Iran. Int J Prev Med. 2010;1(4):247.

49. Rashidi M, Salehian O, Vaezi G. The effects of 12 weeks aerobic continue exercise on cardiovascular function in patients after angioplasty. Pelagia Res Libr Eur J Exp Biol. 2013;(3):203-6.

50. Tsai S, Huang Y, Chen Y, Ting C. Influence of $\beta$-blockers on heart rate recovery and rating of perceived exertion when determining training intensity for cardiac rehabilitation. J Chin Med Assoc. 2015 Sep 1;78(9):520-5.

51. Eston R, Connolly D. The Use of Ratings of Perceived Exertion for Exercise Prescription in Patients Receiving P-Blocker Therapy. Rev Artic Sport Med. 1996;21(3):176-90. 